\title{
Regions and Sub-regions of Lake Trout in the Main Basin of Lake Huron
}

\author{
Ji X $\mathrm{He}^{*}$ \\ Michigan Department of Natural Resources, Fisheries Division, Lake Huron Research Station, 160 East \\ Fletcher Street, Alpena, Michigan, USA \\ *Corresponding author: Ji X He, Michigan Department of Natural Resources, Fisheries Division, Lake \\ Huron Research Station, 160 East Fletcher Street, Alpena, Michigan 49707, USA; E-mail: hej@michigan.gov
}

Received Date: 24 October, 2018; Accepted Date: 21 December, 2018; Published Date: 09 January, 2019

\section{Abstract}

Annual spring fishery independent surveys in the main basin of Lake Huron are analyzed in two steps. Over-year development and recent spatial pattern of lake trout stocks were first revealed based on origin (hatchery vs wild) and size compositions of lake trout and followed by analyses of spatial differences in abundance dynamics. During the 1980s and 1990s, while relative abundance of stocked recruits was similar lake-wide, adult abundance was much lower in northern Lake Huron than in southern Lake Huron. After recent major changes in Lake Huron ecosystem since the early 2000s, stocked recruitment declined lakewide, and wild recruitment increased lake-wide. In southern Lake Huron, the decline of stocked recruitment was especially abrupt, and the recruitment of wild lake trout eventually became weak. The abundance of adult lake trout declined with decreases in stocked recruitment in southern Lake Huron; but was stable in northern Lake Huron. The abundance of wild adults increased in both northern and southern Lake Huron, but the increase was more rapid in northern Lake Huron than in southern Lake Huron. Fisheries in both northern and southern Lake Huron are under similar management, and the harvest policy allows for adult annual mortality of 40-45\%. The survey findings indicate that during the 1980-1990s adult mortality in northern Lake Huron must be much higher than southern Lake Huron and the mortality limit; recently, however, it must become much lower than southern Lake Huron and the mortality limit. The contrasts between northern and southern Lake Huron suggest that the current harvest policy is sustainable only when recruitment is stable and sufficiently high, such as in early years with very low post-stocking mortality of lake trout yearlings.

\section{Keywords}

Fish population balance; fisheries management with regime shift; lake Huron; lake trout; relative abundance; spatial delimitation

\section{Introduction}

Poor understanding of the spatial delimitation and spatial differences in recruitment of lake trout (Salvelinus namaycush) has become a major issue for understanding lake trout status and trends in the main basin of Lake Huron. Lake trout is a native top piscivore in the Laurentian Great Lakes, and Lake Huron lake trout were extirpated by the end of the 1940s, due to sea lamprey (Petromyzon marinus) induced mortality and fishing mortality [1,2]. The current Lake Huron population was rebuilt from hatchery stocking, along with control of sea lamprey abundance and fishery regulation $[3,4,5]$.

As lake trout biomass was building up, and predation pressure by lake trout and other major piscivores continued to increases, the population of non-native prey fish alewives (Alosa pseudoharengus) eventually collapsed by the early 2000s [6,7], followed by two major changes in lake trout status. The dramatic decreases in recruitment of stocked lake trout were due to the loss of predation buffer provided by alewives [7,8], while the rapid increases in recruitment of wild lake trout $[9,10]$ were benefitted from elimination of alewife's adverse effects on native fish reproduction $[11,12,13]$.

Currently, in the main basin of Lake Huron, spatial management units of lake trout fisheries were based on statistical districts (Figure 1) that were established in the first half of the last century $[14,15]$. The ecological relevance of those statistical districts, for current fisheries management in the ecosystem that has changed continuously, needs to be further investigated, as lake-wide indices of the stock assessment were often leading to difficulty in their interpretation, and greater uncertainty in management decisions.

There are two separate approaches to spatial delimitation of fish populations. One is to distinguish stocks that are reproductively segregated, and another is to recognize differences in temporal 
patterns of the fish populations between adjacent spatial locations [16,17]. In Lake Huron, major sites of lake trout reproduction included Thunder Bay, Drummond Island, and offshore reefs in the middle of the lake $[18,19,20]$. The two spawning stocks in Drummond Island and Thunder Bay are reproductively segregated, and lake trout from both sites have long southward movements after spawning [21]. Thus, the statistical districts of MH-1 and MH-2 should be combined as one management unit including adjacent Ontario waters of $\mathrm{OH}-1$ and $\mathrm{OH}-2$ (figure 1), and the boundary between $\mathrm{MH}-2$ and $\mathrm{MH}-3$ should be modified to be consistent with the boundary between $\mathrm{OH}-2$ and $\mathrm{OH}-3$, such that the Thunder Bay would be a part of the southern Lake Huron figure 1.

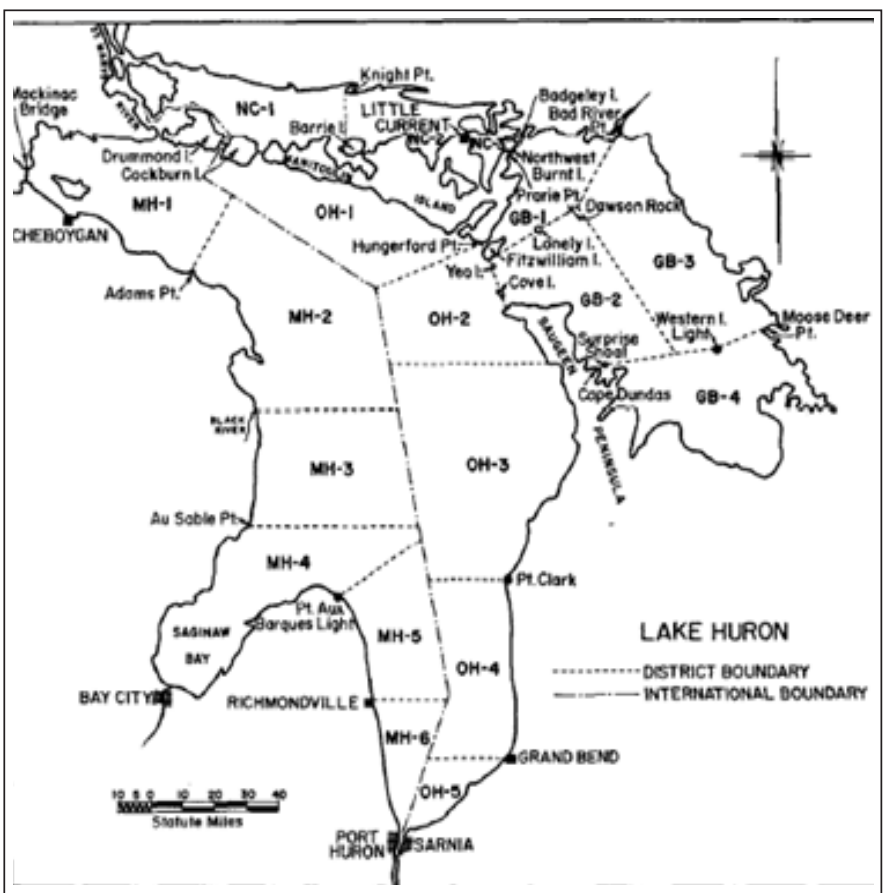

Figure 1: Lake Huron map showing statistical districts

The implied combination of existing statistical districts and modification of their boundaries are believed to be instrumental for better understanding lake trout status and trends and for regionally explicit management of the fisheries, but their merit should be further confirmed by temporal and spatial patterns of the fish populations. In this paper, annual spring gillnetting surveys in US waters of Lake Huron are analyzed. The spring surveys have provided the only time series that has a complete coverage of the process of lake trout rehabilitation since $1970[2,10]$, and has a complete coverage from Drummond Island in the north to the Thumb area in the south figure 1.

Using similarity and differences in population dynamics to reveal spatial patterns is a complex challenge [17], and ideally spatial boundaries need to be decided first independently and objectively. The complicity can be reduced, and the independence and objectivity can be maintained by recognizing two aspects of the balance between recruitment and adult mortality. Abundance dynamics is one of the two aspects, and another is the development of size composition [22,23]. In Lake Huron, population balance of lake trout is also reflected by recent decreases of hatchery-stocked lake trout and increases of wild lake trout. In this paper, lake trout origin-and-size compositions were first used to determine (1) over-year patterns of the population build-up, (2) the most recent spatial patterns, and (3) if Thunder Bay should be included as a part of northern or southern Lake Huron. Then, to further investigate how major factors have influenced lake trout status and trend, the temporal patterns of relative abundance were compared between northern and southern Lake Huron.

\section{Methods}

The annual spring gillnetting surveys were conducted in late April through early June [10] and covered near shore areas with depth range of 30-200 $\mathrm{ft}(10-60 \mathrm{~m})$. In recent years, a survey transact from shallow to deep waters was always implemented with four depth strata: 30-50, 50-100, 100-150, and > $150 \mathrm{ft}$ (9.1$15.2,15.2-30 \mathrm{~m}, 30.5-45.7$, and $>45.7 \mathrm{~m}$ ). The surveys were using overnight bottom-set multifilament nylon gillnets, the gillnets were $6 \mathrm{ft}$ tall $(1.83 \mathrm{~m})$ and consisted of nine $100 \mathrm{ft}(30.5 \mathrm{~m})$ panels with stretched mesh sizes ranging from 2 to 6 inches (50.8-152.4 $\mathrm{mm})$ in 0.5 -inch $(12.7 \mathrm{~mm})$ increments. Summer surveys (late June - August) conducted by multiple agencies were not included in this paper, because these summer surveys in general had much lower catch rates, often came with biased size composition, and their implement was also restricted in local areas. Fall gillnetting surveys (late October - early November) on spawning reefs were also not included in this paper, because they mostly represent spawning aggregations of lake trout at spawning sites.

Every year the spring survey maintained 10-14 survey sites, although in a statistical district such as $\mathrm{MH}-1$ (figure. 1), exact survey locations varied a lot in early years. Distribution of those survey sites reflected an implicit consideration of six sub-regions in the main basin of Lake Huron (Table 1, sub-regions 1-4 and 6-7). Thunder Bay (sub-region 5) was one additional location to be merged with North Central (sub-region 4) or South Central (sub-region 6) based upon the analyses in this paper.

\section{Temporal and spatial patterns of origin-and-size composition}

Annual sample size of lake trout varied between 273-2198 fish since 1976, including hatchery-stocked and wild lake trout that were identified and separated based upon the presence or absence of a fin clip, and then all fish samples were further divided into four size groups based on total length (TL): $<17$ inch $(<=410$ $\mathrm{mm}), 17-21$ inch $(431 \mathrm{~mm}<\mathrm{TL}<=533 \mathrm{~mm}), 21-29$ inch $(533$ $\mathrm{mm}<\mathrm{TL}<737 \mathrm{~mm})$, and $>29$ inch $(>=737 \mathrm{~mm})$. The cut-off between size groups was based on Eshenroder and Koonce [24], who recommended 4-inch increments starting from total length of 1 inch $(25.4 \mathrm{~mm})$. The contribution by each of these eight origin-and-size groups to annual survey catch was calculated as proportion, and principal component analyses (PCA) were used 
to summarize the comparisons and patterns over years. The analyses of temporal patterns were focused on the recent 28 years, 1991-2018, given the fact that the recent hatchery-to-wild population transition was started in the early 2000s $[9,10]$.

Based on the resulted patterns that the population has been changing rapidly and continuously, four most recent short periods were defined for analyzing spatial patterns: 2009-2011, 20122013, 2014-2015 and 2016-2018. For each of these 2-3year short periods, to the total survey catch from a given sub-region, the contribution by each of the eight origin-and- size groups was calculated as proportion, and principal component analyses (PCA) were used to summarize the comparisons and patterns among these sub-regions.

If the North Central and South Central (sub-regions 4 and 6) are more similar to each other in comparison to the first three sub-regions in the north and the Thumb area in the south (table 1; figure 1), the spatial pattern would suggest three large regions in the main basin of Lake Huron: the north (MH-1), the central (North Central and South Central), and the south (the Thumb). If South Central differs from North Central, and was more similar to the Thumb, the spatial pattern would suggest two large regions: the north that includes $\mathrm{MH}-1$ and North Central, and the south that includes South Central and the Thumb.

\begin{tabular}{|l|l|l|}
\hline Code & Name & Survey sites \\
\hline 1 & $\begin{array}{l}\text { MH-1 North } \\
\text { East }\end{array}$ & $\begin{array}{l}\text { Cedarville East, Detour West, } \\
\text { Drummond Island East and West }\end{array}$ \\
\hline 2 & $\begin{array}{l}\text { MH-1 West } \\
\text { Central }\end{array}$ & $\begin{array}{l}\text { St. Ignace, Mackinaw, Bob Island } \\
\text {. Raynolds Reef, Spectacle Reef }\end{array}$ \\
\hline 3 & $\begin{array}{l}\text { MH-1: South } \\
\text { West }\end{array}$ & Hammond Bay, Rogers City \\
\hline 4 & $\begin{array}{l}\text { North Cen- } \\
\text { tral }\end{array}$ & $\begin{array}{l}\text { Rockport-Nordmeer, Presque Isle } \\
\text { in MH2 }\end{array}$ \\
\hline 5 & Thunder Bay & South Point \\
\hline 6 & South Central & Harrisville, Oscoda in MH3 \\
\hline 7 & The Thumb & $\begin{array}{l}\text { Port Austin, Harbor Beach North } \\
\text { and South, Port Sanilac in MH4-6 }\end{array}$ \\
\hline
\end{tabular}

Table 1: Survey sites within each statistical district (figure 1) reorganized into sub-regions of the main basin of Lake Huron, excluding Saginaw Bay.

\section{Lake trout relative abundance and the differences in temporal patterns between regions}

For each of the large regions resulted from the above analyses, annual average catch per unit of effort (CPUE) was calculated on a log scale, where CPUE was calculated as the number of lake trout per $1000 \mathrm{ft}$ ( $305 \mathrm{~m}$ ) of gill net from each lift, including those with zero catch; log transformation of CPUE was calculated as $\ln (\mathrm{CPUE}+1.0)$, such that for those lifts with zero catch the log scale CPUE was also zero [25]. The statistics were calculated separately for all juveniles ( $<21$ inches or $533.4 \mathrm{~mm}$ of total length) and all adults ( $>=21$ inches or $533.4 \mathrm{~mm}$ of total length), although the size cut off was only an approximate separation for juvenile and adult lake trout $[26,27]$. The same statistics were also calculated for wild juveniles and wild adults separately. Temporal patterns of those statistics were compared between regions.

\section{Results}

Major transitions with Lake Huron Lake trout were apparent during the past 28 years (Figure 2), and the first two principal components explained $93 \%$ of variations in lake trout origin-and-size composition. Prior to the end of 1990s, the population was still dominated by hatchery-stocked juveniles, followed by the dominance of hatchery-origin adults during the 2000s, and overall

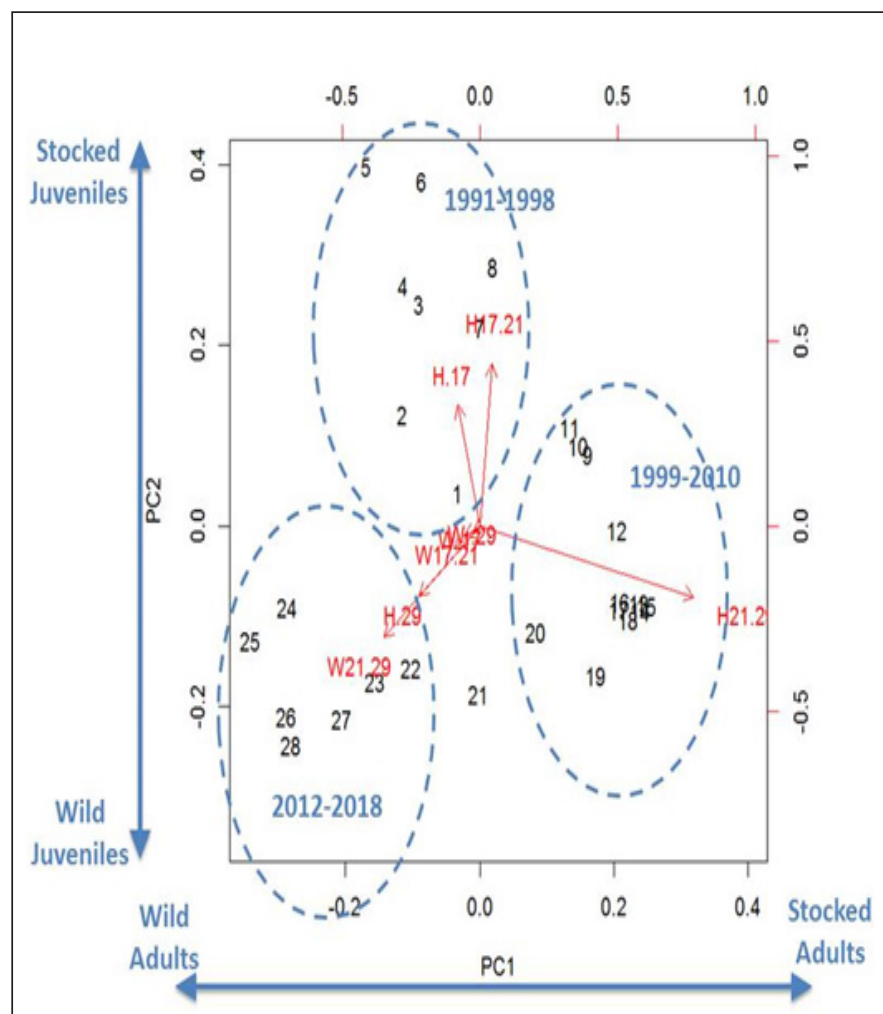

Figure 2: Temporal pattern of lake trout origin-and-size composition analyzed from principal component analysis.

Arrow lines indicating how each component of annual survey catch is correlated to the first and second principal components. H17 is stocked lake trout less than 17 inches, H17-21 is stocked lake trout between 17-21 inches, H21-29 is stocked lake trout between 21-29 inches, and H29 is stocked lake trout larger than 29 inches. Similarly, W17 is wild lake trout less than 17 inches, W17-21 is wild lake trout between 17-21 inches, W2129 is wild lake trout between 21-29 inches, and W29 is wild lake trout larger than 29 inches. The data are proportions of each of those eight origin-and-size groups contributing to the total survey catch in a year. Point values 1-28 are symbols indicating years of 1991-2018. Those symbols are plotted based on their scores of the second principal component versus the first principal component. 
more important contribution by wild lake trout in the most recent years. The dominance of stocked juveniles indicated high adult mortality in early years; very high adult contribution of hatchery origin indicated drops in recruitment of stocked fish, and the recent resurgence of wild lake trout included a relatively more balanced size composition.

Spatial differences in stock development were also apparent (Figure 3). For each of the four recent short periods: 2009-2011, 2012-2013, 2014-2015 and 2016-2018, the first two principal components explained $97 \%, 78 \%, 86 \%$ and $88 \%$ of variations of lake trout origin-and size composition. The first three principal components explained 99\%, 95\%, 96\%, and 97\%, respectively. The sub-regions 1, 2, and 3 always showed stronger recruitment signals than other sub-regions (Figure 3). Near end of the time period with dominance of hatchery-origin adults (Figure 3a), and at beginning of the period with increased contribution of wild lake trout (Figure $3 \mathrm{~b}$ ), the strongest signal of wild adults and wild recruitment was in $\mathrm{MH}-1$ North East (sub-region 1), but in more recent years (Figures $3 \mathrm{c}-\mathrm{d}$ ), the strongest signal was in $\mathrm{MH}-1$ South West (sub-region 3).

\section{Figure 3a}

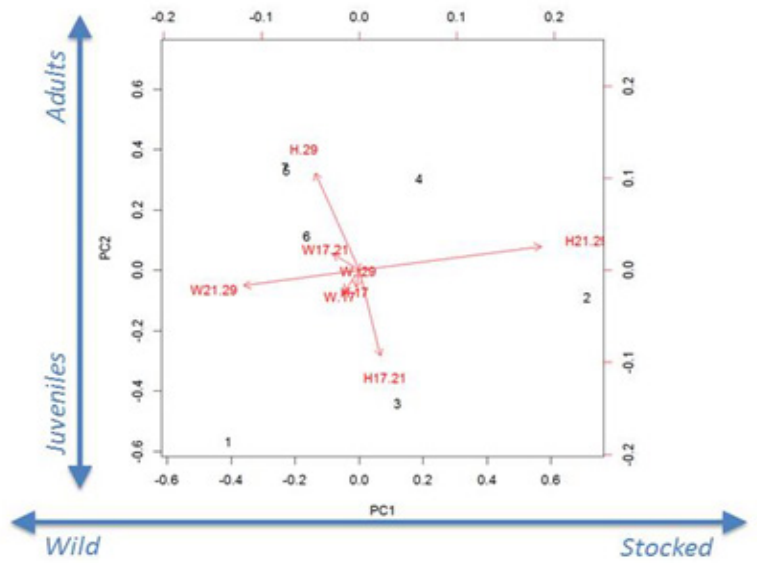

\section{Figure $3 b$}

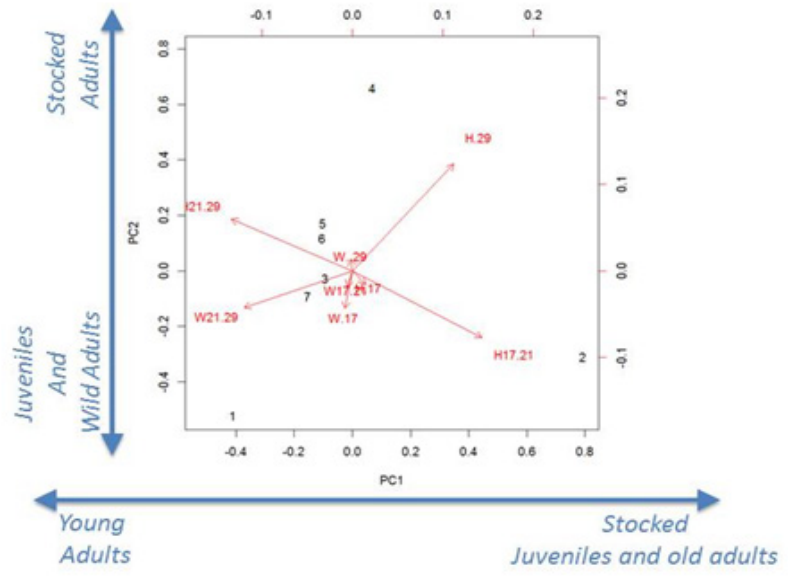

\section{Figure 3c}

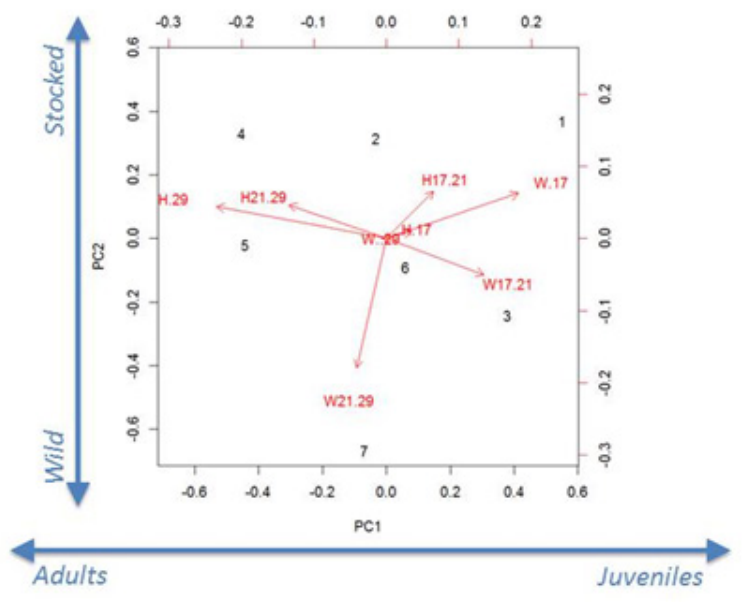

\section{Figure 3d}

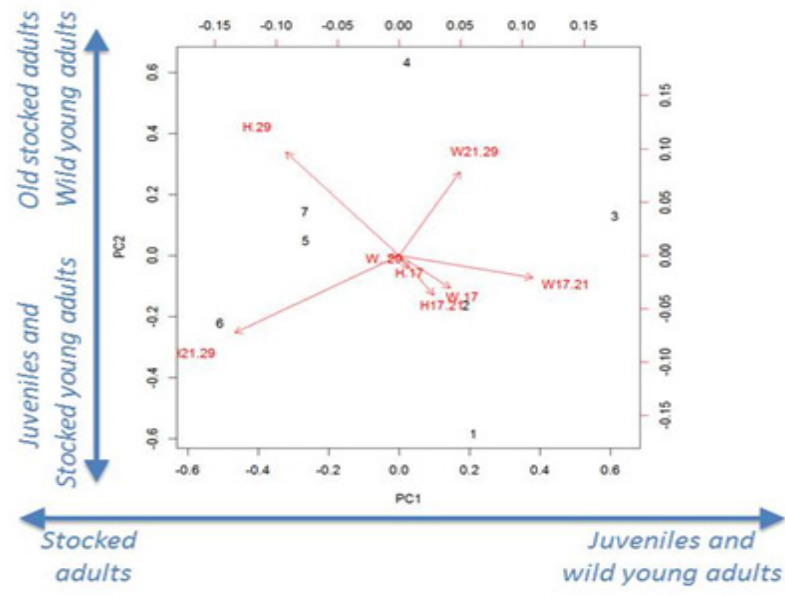

Figure 3: Spatial patterns of lake trout origin-and-size composition analyzed from principal component analyses, based on data from a) 2009-2011, b) 2012-2013, c) 2014-2015, and d) 2016-2018.

Eight components of the total survey catch from a sub-region are the same as defined in Figure. 1 (see also the text), but the data are proportions of each of those eight groups contributing to the survey catch from a sub-region. Arrow lines indicating how each component is correlated to the first and the second principal components. Point values 1-7 are symbols indicating sub-regions as detailed in Table 1. Those symbols are plotted based on their scores of the second principal component versus the first principal component.

The West Central area of MH-1 (sub-region 2) showed strong dominance of hatchery-origin adults and stocked recruitment (figures 3a-3c), except for the most recent three years where the contributions from stocked and wild recruitments were almost equal (Figure 3d). 
South Central (sub-region 6) and the Thumb (sub-region 7) differed from North Central (sub-region 4) in the relative contribution of wild lake trout (figure 3), and the difference must stem from the sources of recruitment. At end of the time period with dominance of hatchery-origin adults (figure $3 \mathrm{a}$ ), and in early years of wild lake trout resurgence (figures $3 b-c$ ), the population in South Central and the Thumb had greater contributions from wild adults and wild recruitment. By the most recent three years (figure $3 \mathrm{~d}$ ), however, the pattern reversed and the population in North Central had the greatest contribution from wild adults and wild recruitment. Thunder Bay (Sub-region 5) was more similar to South Central (Sub-region 6) and even the Thumb (Sub-region 7), in regard to the relative contribution of wild adults and wild recruitment (figure 3), although in 2014-2015 Thunder Bay was similar to North Central (sub-region 4) in adult dominance and lack of juvenile recruitment (figure $3 \mathrm{c}$ ).

The above results suggested that the main basin of Lake Huron includes two ecological regions: northern and southern Lake Huron and Thunder Bay is a part of southern Lake Huron. Consistent with the above results, temporal trends of lake trout relative abundance showed differences between the two large regions (Figures 4-5).

During the 1980s and 1990s juvenile CPUE was relatively stable and similar between northern and southern Lake Huron, suggesting that post-stocking survival was high lake-wide during those early years. Meanwhile, Adult CPUE was much lower in northern Lake Huron than in southern Lake $\mathrm{Hu}$ ron, suggesting that adult mortality in northern Lake Huron was much higher than in southern Lake Huron. Those findings and implications were consistent with previous studies $[28,29]$.

During the 2000s, juvenile CPUE declined in both regions due to the decline in recruitment of stocked lake trout. The decline appeared to be relatively gradual in northern Lake Huron, but dramatic in southern Lake Huron. Adult CPUE followed juvenile CPUE to decline in southern Lake Huron (figure 4), although adult mortality stayed about the same as in previous years and was about the limit of adult mortality [8]. Adult CPUE was relatively stable in northern Lake Huron, strongly suggesting that adult mortality in northern Lake Huron became much lower than southern Lake Huron.

During the most recent 20 years or so (figure 5), the continued increases in CPUE of wild adults appeared to be stronger initially in southern Lake Huron but ended very similar between northern and southern Lake Huron. Near end of the time series, the CPUE of wild juveniles were much higher in northern Lake Huron than southern Lake Huron. All juveniles together, the recent highest CPUE were in 2014 and 2015, corresponding to the 2010- and 2011-year classes and were contributed mostly by wild lake trout (figures 4-5).
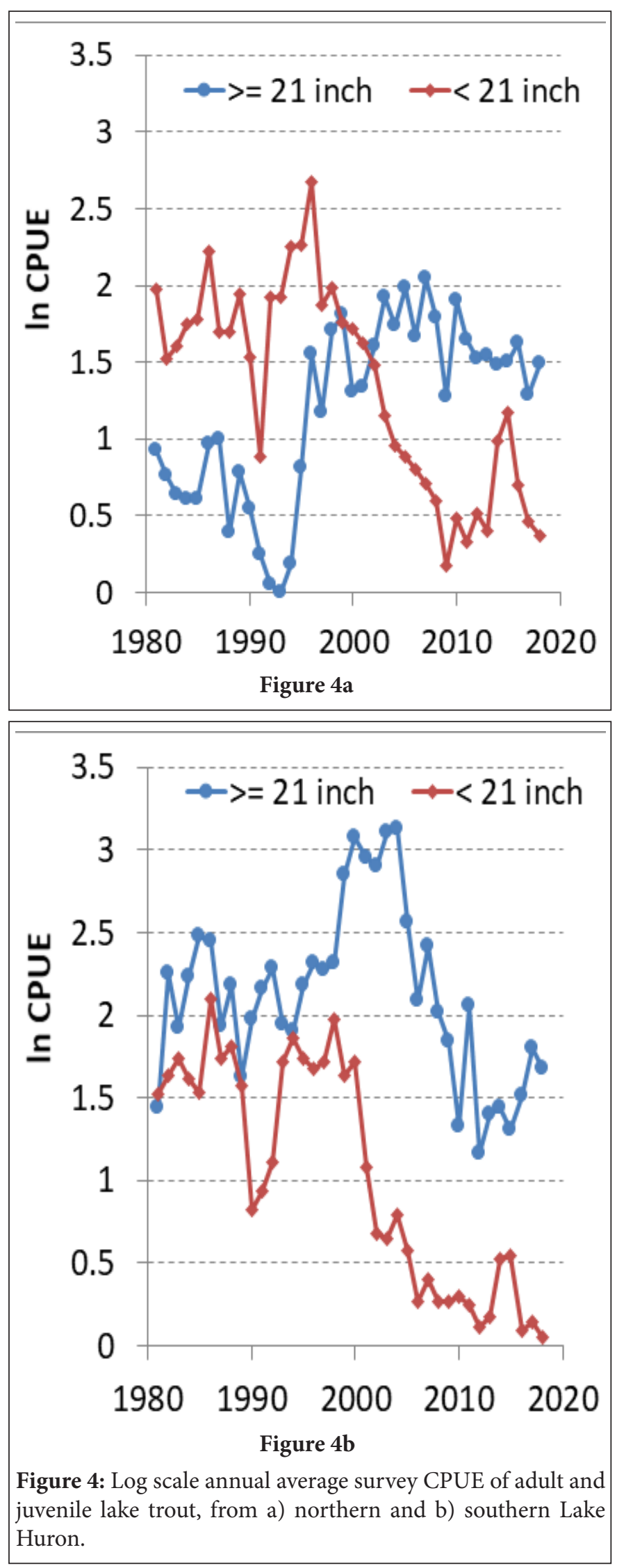

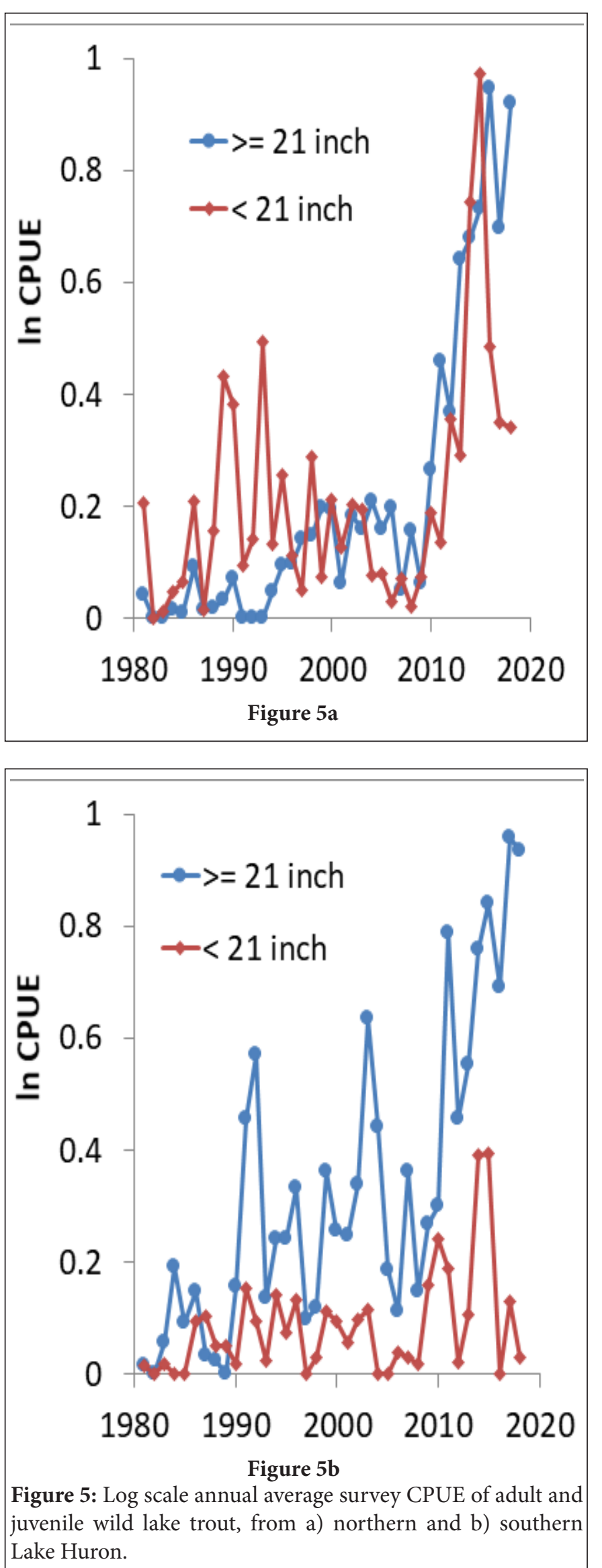

\section{Discussion}

Stocked recruitment, wild recruitment, and adult mortality are the three major factors that have influenced lake trout abundance in the main basin of Lake Huron. The results of this study indicate that northern and southern Lake Huron appear to be two ecological regions. In Northern Lake Huron, the sources of recruitment are sub-regions 1, 2, and 3 (Table 1, Figure 2), and wild recruitment mostly comes from the two shorelines from Cedarville East to Drummond Island East and from Hammond Bay to Rogers City South. In southern Lake Huron, the sources of recruitment include offshore reefs and Thunder Bay. Northern and southern Lake Huron also differ from each other in adult mortality, while natural mortality is believed to be the same in both regions as in Lake Ontario [30], and sea lamprey induced mortality should be also similar between the two regions since end of the 1990s [31].

During the 1980s and 1990s, stocked recruitment was similar between northern and southern Lake Huron, Since the early 2000s, the decline in stocked recruitment was mostly due to the decline and eventually collapse of the alewife population and the loss of predation buffer provided by alewives $[7,8]$. There could be two additional factors that made the recruitment decline more dramatic and two years earlier in southern Lake Huron than in northern Lake Huron. Prior to the collapse of alewives, the relative abundance of adult lake trout was much higher in southern Lake Huron (> 20 lake trout per $1000 \mathrm{ft}, 305 \mathrm{~m}$, of gillnets) than in northern Lake Huron ( $>7$ lake trout per $1000 \mathrm{ft}, 305 \mathrm{~m}$, of gillnets); at the same time annual stocking of lake trout in southern Lake Huron was changed from offshore reefs to near shore stocking sites.

Adult abundance rapidly declined with decreases in stocked recruitment in southern Lake Huron but was relatively stable in northern Lake Huron. This comparison implied much lower adult mortality in northern Lake Huron than southern Lake Huron since the early 2000s, although until the late 1990s adult mortality was much higher in northern Lake Huron than in southern Lake Huron. Annual commercial harvest of lake trout in northern Lake Huron averaged more than 150,000 kg since the year of 2000. The commercial harvest was mostly from sub-regions 1,2 , and 3 (Table 1, Figure1), and there was no commercial fishing in Michigan Waters of North Central (Sub-region 4, Table 1, Figure1). It is fortunate that lake trout fishery management has involved the combination of quota control and protection zones, and in northern Lake Huron the combination of no-fishing and no commercial fishing zones is nearly $40 \%$ of lake trout habitats. Future studies should further evaluate how no-fishing and no commercial fishing zones have contributed to the achievement of low adult mortality $[32,33,34]$.

In northern Lake Huron, the relatively gradual declines in juvenile CPUE might also involve decreases in size-specific catchability after the declines and eventually collapse of the alewife population, as juvenile lake trout were increasingly distributed in 
water columns of much deeper waters. In contrast, the dramatic decline in juvenile CPUE in southern Lake Huron was closely followed by subsequent declines in adult CPUE, and thus truly presented abrupt decline in absolute abundance. Future studies should further investigate survey and fishing catchability as related to the bathymetric difference between northern and southern Lake Huron.

In comparison to northern Lake Huron, wild recruitment in southern Lake Huron did not continue to show strong increases, suggesting that the contribution from Thunder Bay and offshore reefs must become questionable in the most recent years. There was no evidence that this was always the case in earlier years. More studies are needed to investigate if the weak recruitment of wild juveniles in southern Lake Huron is related to the recent major changes in the food web. In particular, the spring peak of primary and secondary production might have been maintained only in sub-regions 1, 2 and 3 of northern Lake Huron, but such production peak might have shifted from the spring to the fall in southern Lake Huron.

It is informative to compare the recent status and trends of Lake Huron lake trout with the history of lake trout rehabilitation in Lake Superior. During the late 1970s and early 1980s, increase in the abundance of wild lake trout in Lake Superior was accompanied by steady decline in stocked lake trout, due to density effects on post-stocking survival $[27,35,36]$. Similar declines in post-stocking survival occurred with much lower adult density in Lake Huron than in Lake Superior, probably because the Lake Superior ecosystem did not involve any dramatic food-web changes such as the collapse of alewives in Lake Huron. Currently, although lake trout growth rate and body condition were not as high as with abundant alewives [37,38,39], the abundance of wild adult lake trout has continued to increase in Lake Huron.

The current strategy of lake trout fishery management in Lake Huron was designed in early years to meet the challenge of reducing adult mortality, and since the late 1990s the lake wide increases in adult abundance was largely due to decreases in adult mortality. The limit of total mortality was set as $40 \%$ or $45 \%$ $[15,40,41]$, and annual recruitment of stocked lake trout in those early years was rarely far from an among-year average. The recent decreases in adult abundance in southern Lake Huron, however, were largely due to declines in recruitment, and so far the first pulse of wild recruitment lake wide did not fully compensate for the declines in stocked recruitment, although the strongest wild year class in northern Lake Huron could be equivalent to the annual stocking level of one million yearlings based on the comparison of juvenile CPUE between 2003-2004 and 20142015 (figures $4 \mathrm{a}$ and $5 \mathrm{a}$ ). The relatively stable adult abundance in northern Lake Huron was mostly attributed further decline in adult mortality substantially below the mortality limit, while overall recruitment in northern Lake Huron was also declined.

The recent decline in recruitment should not be treated just as an unusual case of annual variation. Rather, it is wise to recognize a regime shift where recruitment drops and stays at a very low level for a period of years $[42,43,44]$. Consequently, a previously sustainable mortality rate may become unsustainable, as illustrated by the contrast in the status and trends of adult lake trout between southern and northern Lake Huron. When changes in productivity is viewed as a type of autocorrelation $[45,46,47]$, it requires fishing mortality to be much lower if a policy of constant mortality is maintained $[48,49]$. Alternatively, when potential changes in productivity are taken into consideration $[47,50,51]$, comprehensive stock assessments should come with periodical reviews and timely updates of fishery management strategies $[52,53,54]$.

\section{Acknowledgments}

This study was funded by the Federal Aid in Sport Fish Restoration Program F-61-R to Michigan Department of Natural Resources, Fishery Division, Study 230451, at Lake Huron Research Station. I thank Todd Wills for providing a review of the manuscript.

\section{References}

1. Hile R (1949) Trends in the lake trout fishery of Lake Huron through 1946. Trans Am Fish Soc 76:121-147.

2. Eshenroder RL, Payne NR, Johnson JE, Bowen C II, Ebener MP (1995) Lake trout rehabilitation in Lake Huron. J Great Lakes Res 21: 108-127.

3. Hansen MJ (1999) Lake trout in the Great Lakes: basinwide stock collapse and binational restoration. In: Taylor WW, Ferreri CP (eds.), Great Lakes fisheries policy and management: a binational perspective. Michigan State University Press, East Lansing, Michigan, USA. Pp. 417-453.

4. Krueger CC, Ebener MP (2004) Rehabilitation of lake trout in the Great Lakes: past lessons and future challenges. In: Gunn JM, Stedman RJ, Ryder RA. (eds.). Boreal Shield Watersheds: Lake trout ecosystems in a changing environment. CRC Press LLC, Boca Raton, Florida, USA Pp. 37-56.

5. Muir AM, Krueger CC., Hansen MJ (2013) Re-establishing lake trout in the Laurentian Great Lakes: past, present, and future. In: Taylor WW, Lynch AJ, Leonard NJ (Eds.). Great Lakes fisheries policy and management: a binational perspective. Michigan State University Press, East Lansing, Michigan, USA. Pp. 533-588.

6. Riley SC, Roseman EF, Nichols SJ, O Brien TP, Kiley CS et al. (2008) Deepwater demersal fish community collapse in Lake Huron. Trans Am Fish Soc 137:1879-1890.

7. He JX, Bence JR, Madenjian CP, Pothoven SA, Dobiesz NE et al. (2015) Coupling age-structured stock assessment and fish bioenergetics models: a system of time-varying models for quantifying piscivory patterns during the rapid trophic shift in the main basin of Lake Huron. Can J Fish Aquat Sci 72:7-23.

8. Johnson JE, He JX, Fielder DG. (2015) Rehabilitation stocking of Walleyes and Lake Trout: restoration of reproducing stocks in Michigan Waters of Lake Huron. N Am J Aquac 77: 396-408.

9. Riley SC, He JX, Johnson JE, O Brien TP, Schaeffer JS (2007) Evidence of widespread natural reproduction by lake trout Salvelinus namaycush in the Michigan waters of Lake Huron. J Great Lakes Res 33: 917-921.

10. He JX, Ebener MP, Riley SC, Cottrill A, Kowalski A et al. (2012) Lake 
Trout status in the main basin of Lake Huron, 1973-2010. N Am J Fish Manag 32: 402-412.

11. Madenjian CP, O'Gorman R, Bunnell DB, Argyle RL, Roseman EF et al. (2008) Adverse effects of alewives on Laurentian Great Lakes fish communities. N Am Fish Manag 28: 263-282.

12. Fitzsimons JD, Brown S, Brown L, Honeyfield D, He J et al. (2010) Increase in lake trout reproduction in Lake Huron following the collapse of alewife: Relief from thiamine deficiency or larval predation? Aquat Eco Heal Manag 13:73-84.

13. Riley SC, Rinchard J, Honeyfield DC, Evans AN, Begnoche L (2011) Increasing thiamine concentrations in lake trout eggs from lakes Huron and Michigan coincide with low alewife abundance. N Am Fish Manag 31:1052-1064

14. Smith SH, Buettner HJ, Hile R (1961) Fishery statistical districts of the Great Lakes. Great Lakes Fish. Comm., Tech. Rep. No.2. Ann Arbor, Michigan, USA

15. Ebener MP (1998) A Lake Trout Rehabilitation Guide for Lake Huron. Great Lakes Fishery Commission, Ann Arbor, Michigan, USA.

16. Brown EH Jr, Eck GW, Foster NR, Horrall RM, Coberly CE (1981) Historical evidence for discrete stocks of lake trout (Salvelinus namaycush) in Lake Michigan. Can J Fish Aquat Sci, 38: 1747-1758.

17. Cope JM, and Punt AE (2009) Drawing the lines: resolving fishery management units with simple fisheries data. Can J Fish Aquat Sci, 66: $1256-1273$

18. Riley SC, Binder TR, Wattrus NJ, Faust MD, Janssen J et al. (2014) Lake trout in northern Lake Huron spawn on submerged drumlins. J Great Lakes Res, 40: 415-420.

19. Binder TR, Riley SC, Holbrook CM, Hansen MJ, Bergstedt RA et al. (2016) Spawning site fidelity of wild and hatchery lake trout, Salvelinus namaycush, in northern Lake Huron. Can J Fish Aquat Sci, $73: 18-34$

20. Marsden JE, Binder TR, Johnson J, He J, Dingledine N et al. (2016). Five-year evaluation of habitat remediation in Thunder Bay, Lake Huron: comparison of constructed reef characteristics that attract spawning lake trout. Fish Res, 183: 275-286.

21. Binder TR, Marsden JE, Riley SC, Johnson JE, Johnson NS et al. (2017) Movement patterns and spatial segregation of two populations of lake trout Salvelinus namaycush in Lake Huron. J Great Lakes Res, 43:108-118.

22. Swingle HS (1950) Relationships and dynamics of balanced and unbalanced fish populations. Auburn University Agricultural Experiment Station, Bulletin 274, Auburn, Alabama.

23. Beverton RJH, Holt SJ (1957) On the dynamics of exploited fish populations. Fishery Investigation, Series 2, no. 9, Landon.

24. Eshenroder RL, Koonce JF (1984) Recommendations for Standardizing the Reporting of Sea Lamprey Marking Data: A Report from the Ad Hoc Committee. Great Lakes Fishery Commission, Special Publication 84-1.

25. Zar JH (1999) Biostatistical Analysis. Fourth Edition. Prentice Hall. Upper Saddle River, New Jersey.

26. Madenjian CP, DeSorcie TJ, Stedman RM (1998) Maturity schedules of lake trout in Lake Michigan. J Great Lakes Res 24: 404-410.

27. Sitar SP, He JX (2006) Growth and maturity of hatchery and wild lean lake trout during population recovery in Michigan Waters of
Lake Superior. Trans Am Fish Soc 135: 915-923.

28. Wilberg MJ, Bence JR, Johnson JE (2002) Survival of juvenile lake trout stocked in western Lake Huron during 1974-1992. N Am Fish Manag 22: 213-218.

29. Johnson JE, He JX, Woldt AP, Ebener MP, Mohr LC (2004) Lessons in rehabilitation stocking and management of lake trout in Lake Huron. Am Fish Soc Symp 44: 157-171.

30. Brenden TO, Bence JR, Lantry BF, Lantry JR, Schaner T (2011) Population dynamics of Lake Ontario Lake Trout during 1985-2007. N Am J Fish Manag 31: 962-979.

31. Adams JV, Bergstedt RA, Christie GC, Cuddy DW, Fodale MF et al. (2003). Assessing assessment: can the expected effects of the St. Marys River sea lamprey control strategy be detected?. J Great Lakes Res 29: 717-727.

32. Stefansson G, Rosenberg AA (2005) Combining control measures for more effective management of fisheries under uncertainty: effort limitation and protected areas. Philos Trans R Soc Lond B Biol Sci 360: 133-146.

33. Hilborn R, Micheli F, DeLeo GA (2006) Integrating marine protected areas with catch regulation. Can J Fish Aquat Sci 63: 642-649.

34. Babcock, EA, MacCall AD (2011) How useful is the ratio of fish density outside versus inside no-take marine reserves as a metric for fishery management control rules? Can J Fish Aquat Sci 68: 343359.

35. Hansen MJ, Ebener MP, Schorfhaar RG, Schram ST, Schreiner DR et al. (1994) Declining survival of lake trout stocked during 1963-86 in US waters of Lake Superior. N Am J Fish Manag 14: 395-402.

36. Hansen MJ, Ebener MP, Schorfhaar RG, Schram ST, Schreiner DR et al. (1996) Causes of declining survival of lake trout stocked in U.S. waters of Lake Superior in 1963-1986. Trans Am Fish Soc125: 831-843.

37. He JX, Bence JR (2007) Modeling annual growth variation using a hierarchical Bayesian approach and the von Bertalanffy growth function, with application to lake trout in southern Lake Huron. Trans Am Fish Soc 136: 318-330.

38. He JX, Bence JR, Johnson JE, Clapp D, Ebener MP (2008) Modeling variation in mass-length relations and condition indices of lake trout and Chinook salmon in Lake Huron: a hierarchical Bayesian approach. Trans Am Fish Soc 137: 801-817.

39. He JX, Bence JR, Roseman EF, Fielder DG, Ebener MP (2016) Using time-varying asymptotic length and body condition of top piscivores to indicate ecosystem regime shift in the main basin of Lake Huron: a Bayesian hierarchical modeling approach. Can J Fish Aquat Sci 73: 1092-1103.

40. Healey MC (1978) The dynamics of exploited lake trout populations and implications for management. J Wild Manag 42: 307-328.

41. Nieland JL, Hansen MJ, Seider MJ, Deroba JJ (2008) Modeling the sustainability of lake trout fisheries in eastern Wisconsin waters of Lake Superior. Fish Res 94: 304-314.

42. Gilbert DJ (1997) Towards a new recruitment paradigm for fish stocks. Can J Fish Aquat Sci 54: 969-977.

43. Beamish RJ, Noakes DJ, McFarlane GA, Klyashtorin L, Ivanov VV et al. (1999) The regime concept and natural trends in the production of Pacific salmon. Can J Fish Aquat Sci 56: 516-526. 
44. Vert pre KA, Amoroso RO, Jensen OP, Hilborn R (2013) Frequency and intensity of productivity regime shifts in marine fish stocks. Proceedings of National Academy of Sciences 110: 1779-1784.

45. Spencer PD (1997) Optimal harvesting of fish populations with nonlinear rates of predation and autocorrelated environmental variability. Can J Fish Aquat Sci 54: 59-74.

46. Deroba JJ, Bence JR (2008) A review of harvest policies: understanding relative performance of control rules. Fish Res 94: 210223.

47. Hawkshaw M, Walters C (2015) Harvest control rules for mixedstock fisheries coping with autocorrelated recruitment variation, conservation of weak stocks, and economic well-being. Can J Fish Aquat Sci, 72: 759-766.

48. Clark WG (1993) The effect of recruitment variability on the choice of a target level of spawning biomass per recruit. In: Kruse G, Marasco RJ, Pautzke C, Quinn II TJ (eds) Proceedings of the international symposium on management strategies for exploited fish populations. University of Alaska, Alaska Sea Grant College Program Report 93-02, Fairbanks, Pg.no 233-246.

49. Clark WG (2002) F35\% revisited ten years later. N Am J Fish Manag 22: $251-257$.
50. Koslow JA (1989) Managing nonrandomly varying fisheries. Can J Fish Aquat Sci 46: 1302-1308.

51. Collie JS, Peterman RM, Zuehlke BM (2012) A fisheries risk-assessment framework to evaluate trade-offs among management options in the presence of time-varying productivity. Can J Fish Aquat Sci 69: 209-223.

52. Martell SJD, Walters CJ, Hilborn R (2008) Retrospective analysis of harvest management performance for Bristol Bay and Fraser River sockeye salmon (Oncorhynchus nerka). Can J Fish Aquat Sci 65: 409-424.

53. A'mar ZT, Punt AE, Dorn MW (2009) The impact of regime shifts on the performance of management strategies for the Gulf of Alaska walleye pollock (Theragra chalcogramma) fishery. Can J Fish Aquat Sci, 66: 2222-2242.

54. Szuwalski CS, Punt AE (2013) Fisheries management for regime-based ecosystems: a management strategy evaluation for the snow crab fishery in the eastern Bering Sea. ICES J Mar Sci 70: 955-967. 


\section{倜 \\ IC \\ OPEN ACCESS PUBLICATIONS}

submit your manuscripts at

www. norcaloa.com 